\title{
Tympanostomy Tube
}

National Cancer Institute

\section{Source}

National Cancer Institute. Tympanostomy Tube. NCI Thesaurus. Code C122608.

A hollow tube that is inserted into the eardrum through a surgical incision. 